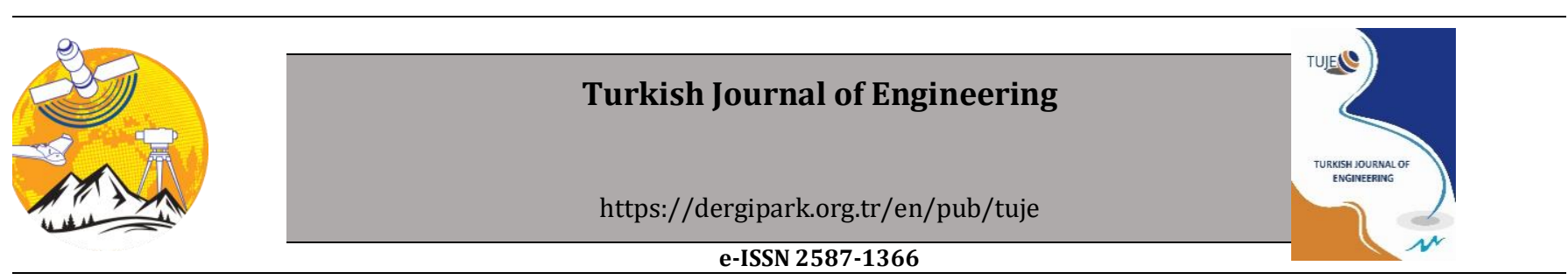

\title{
A statistical investigation to determine dominant frequency of layered soil profiles
}

\author{
Ahmet Güllü*1®, Serkan Hasanoğlu 2 (®) \\ ${ }^{1}$ Istanbul Gedik University, Faculty of Engineering, Department of Civil Engineering, Istanbul, Turkey \\ 2 Kocaeli University, Faculty of Engineering, Department of Civil Engineering, Kocaeli, Turkey
}

\author{
Keywords \\ Energy based seismic design \\ Layered soil profile \\ Fundamental period \\ Resonance
}

\begin{abstract}
Energy based seismic design getting attraction since it accounts for all structural (hysteretic behavior of structural members), earthquake (amplitude, duration and frequency content) and soil (bearing capacity, frequency content) characteristics. To develop an efficient energy based seismic design procedure, accurate determination of the fundamental periods of the soil deposits is crucial. Hence, several analytical, numerical and approximate methods were suggested in the literature to find out fundamental periods of layered soil profiles. However, practitioners tend to use the simplest and the roughest methods, generally. In this particular research, a statistical study was performed to find out the best fit coefficient for the total travel time having minimum standard deviation. In the analyses, the calculated fundamental periods of 459 different soil profiles are compared with the results of almost exact analytical equations. Resultantly, the equation generally preferred by the practitioners is improved. It is proved that the improved equation has higher accuracy with lowest standard deviation and higher correlation. Therefore, using the improved equation to determine fundamental period of the layered soil profiles is highly suggested.
\end{abstract}

\section{INTRODUCTION}

Energy-based seismic design is a promising procedure in structural and earthquake engineering since it accounts for all soil, structure and earthquake characteristics, (Güllü et al. 2019). Moreover, energy is a scalar quantity, which makes modal combinations easier. To develop an efficient energy-based design procedure, determining the dominant frequencies of soil deposits is crucial. It is also well-known for conventional design procedures that local geological conditions (especially near surface soil deposits) has a direct effect on vulnerability of structures against strong ground motions (Sextos et al. 2018). Greater input energy will be imparted to the structures having similar frequencies with the soil layers i.e. the structure will be exposed to resonance. As an example, it was reported that low- and mid-rise buildings in the Katmandu Valley almost unaffected by great 2015 Gorkha, Nepal earthquake since long period nature of the earthquake (Goda et al. 2015).

Characteristics of seismic waves (e.g. amplitude, frequency content) alter during the propagation of the wave through heterogeneous soil deposits. This phenomenon is primarily dependent on modal characteristics of the layered soil profiles. Particularly, amplification is dominant in the vicinity of the fundamental frequency of the soil deposit (Vijayendra et al. 2014).

Even though investigating the strong ground motion records is an easier and suitable way to determine the fundamental period of a soil site, finding data for any place is not possible. Hence, different procedures have been proposed in the literature for this purpose (Dobry et al.,1976; Gazetas, 1982; Zhao, 1996, 1997; Hadjian 2002; Vijayendra et al. 2014; Urzua et al., 2017; Wang et al.,2018).

Dobry et al. (1976) evaluated several numerical and approximate procedures to determine fundamental periods of layered soil profiles. The numerical method, namely Rayleigh method, provide almost exact results comparing to measured fundamental periods. However, it is fairly complex for more than two layers. Hence, a simplified version of the method was proposed by supposing constant soil density for the layers. In this method, single iteration is sufficient to catch modal shape and fundamental period of the soil profiles, Eqs. (1a-c). 


$$
\begin{gathered}
X(i+1)=X(i)+\frac{H-H_{m i}}{V_{i}^{2}} H_{i} \\
\omega^{2}=4 \frac{\frac{\sum\left[H-H_{m i}\right]^{2}}{V_{i}^{2}} H_{i}}{\sum[X(i)+X(i+1)]^{2} H_{i}}
\end{gathered}
$$

$T=\frac{2 \pi}{\omega}$

In the equations, $H$ is total depth to engineering bedrock, $H_{i}$ and $H_{m i}$ are height and the mid-depth of the $i^{t h}$ layer. Additionally, $X(i)$ and $X(i+1)$ are the first-mode shape at the top and bottom of the $i^{\text {th }}$ soil layer.

A simple approximate method for two-layer soil which yields acceptable results was also suggested by Madera (1970). Dobry et al. (1976), improved this analytical and graphical solution considering constant density for multilayer soil profiles. Combined fundamental period for a two-layer profile, $T_{a-b}$, can be calculated by Eq. (2). In the equation $\rho$ and $h$ are stand for soil density and height, respectively. $T_{a}$ and $T_{b}$ are the fundamental periods of each soil layers.

$$
\tan \left(\frac{\pi}{2} \frac{T_{a}}{T_{a-b}}\right) \tan \left(\frac{\pi}{2} \frac{T_{b}}{T_{a-b}}\right)=\frac{\rho_{b} h_{b} T_{a}}{\rho_{a} h_{a} T_{b}}
$$

where $T_{a}=4 \frac{H_{a}}{V_{a}}$ and $T_{b}=4 \frac{H_{b}}{V_{b}}$.

For the application of the method to a multi-layered soil, firstly $T_{a-b}^{1-2}$ of the top two layers should be calculated. Then, the combined fundamental period of the top three layers $\left(T_{a-b}^{1,2-3}\right)$ can be calculated by considering the top two layers as a single layer with efficient fundamental period of $T_{a-b}^{1-2}$. Fundamental period of the multi-layered soil profile $\left(T_{a-b}^{1,2-n}\right)$ can be obtained easily by repeating the process till the bottommost soil layer. Hadjian (2002) improved the Madera's method (Madera 1970) applying some algebraic manipulations on Eq. (2) and proposed a nongraphical solution.

Although the numerical methods provide accurate results, employing them is a tedious and time-consuming task for practitioners. Thus, several simple and rough methods were generated by researchers. Many practitioners preferred using Eq. (3) to determine fundamental periods of the soil profiles due to its simplicity. In the equation, $H$ is height of soil column on the engineering bedrock, $V_{\text {avg }}$ is weighted average shear wave velocity of the soil layers.

$$
T=4 \frac{H}{V_{\text {avg }}}
$$

Increasing the accuracy of Eq. (3) through a statistical study is the rational of this paper. To serve this purpose
459 layered soil profile data is analyzed. Since the Simplified Rayleigh method has a remarkable accuracy (Dobry et al. 1976), results of the method were considered as "true" values. A novel and simple equation with lower standard deviation and higher correlation is suggested.

\section{Materials and Method}

The data provided by KiK-net of Japan is utilized here as the material. In the method, true dominant frequencies of the soil profiles, which is calculated by Eqs. (1a-b), compared with the results of varied coefficients of Eq. (3). Consequently, the coefficient having the smallest standard deviation is proposed for the quick and robust determination of the fundamental periods of the soil profiles. Details of the data set and analyzing procedures are described in the following sub-sections.

\subsection{Data set}

Since reaching a soil data set of Istanbul could not be possible after many attempts those were made to related division of the municipality, the detailed layered soil profile data provided by KiK-net (Kiban Kyoshin Network) of Japan (National Research Institute for Earth Science and Disaster Resilience) were utilized. KiK-net has 698 stations, and uniformly cover Japan with an average station-to-station distance of about $20 \mathrm{~km}$.

Generally, fundamental periods of layer soil profiles were calculated by considering the engineering bedrock has a shear wave velocity of $760 \mathrm{~m} / \mathrm{sec}$ (Ghofrani et al. 2013, Zhao et al. 2015, Wang et al. 2018) or $700 \mathrm{~m} / \mathrm{sec}$ (Zhao et al., 2006; Zhao and Xu, 2013). In this study, bedrock is considered to be the depth where shear wave velocity reaches to $760 \mathrm{~m} / \mathrm{sec}$.

The data set was filtered according to following conditions in line with Wang et al. (2018);

- The data should be obtained by drilling up to engineering bedrock

- There should be at least two soil layers within the soil depth.

- Minimum shear wave velocity is accepted as 100 $\mathrm{m} / \mathrm{sec}$ since low values of shear wave velocity may occur due to instrumental errors.

After filtering the data set, $459 \mathrm{KiK}$-net soil profiles were chosen to utilize in the analyses. The layered soil profiles which are not utilized in this study are listed in Appendix-1.

\subsection{True determination of fundamental periods}

Assuming constant density for the soil layers is an important characteristic of the Simplified Rayleigh method. The assumption considerably simplify the problem and it is possible to reach almost exact results by just one single iteration. According to Dobry et al. (1976), Simplified Rayleigh method differs only a few percent from the correct value. Thus, the results of the method can be accepted as true values for fundamental period calculations of layered soil profiles. 
The parameters of the method $\left(V_{i}, H_{i}, H\right.$ and $\left.H_{m i}\right)$ are considered layer by layer starting from the bottom of the soil profile. At the lower boundary of the bottommost layer, $X_{i}$ is taken as zero i.e., $X_{i}=X_{1}=0$. Once all $X_{i}$ values are computed by Eq. (1a), fundamental circular frequencies of the soil profile can be calculated by Eq. (1b). Then, it can be converted to the period, easily. Fundamental period calculation of the soil profiles
ABSH03 and CHBH06 by means of Simplified Rayleigh method, are given in Table 1. In the third column of the table, total depths $(H)$ of the soil profiles are given. The fourth and fifth columns are the depth of each layer $\left(H_{i}\right)$ and depth of center of each layer $\left(H_{m i}\right)$. The seventh column is the measured shear wave velocity of the layers. Other columns are calculated by using the data given in these columns.

Table 1. Fundamental period calculation examples by simplified Rayleigh method.

\begin{tabular}{|c|c|c|c|c|c|c|c|c|c|}
\hline $\begin{array}{l}\text { Sta. } \\
\text { ID }\end{array}$ & $\begin{array}{l}\text { Layer } \\
\# \\
\end{array}$ & $\begin{array}{c}\mathrm{H} \\
(\mathrm{m}) \\
\end{array}$ & $\begin{array}{c}\mathrm{H}_{\mathrm{i}} \\
(\mathrm{m}) \\
\end{array}$ & $\begin{array}{l}\mathrm{H}_{\mathrm{mi}} \\
(\mathrm{m}) \\
\end{array}$ & $\begin{array}{c}\mathrm{H}-\mathrm{H}_{\mathrm{mi}} \\
(\mathrm{m}) \\
\end{array}$ & $\begin{array}{c}V_{s, i} \\
(m / s) \\
\end{array}$ & $\begin{array}{c}X_{i} \\
\left(\times 10^{-4}\right) \\
\end{array}$ & $\begin{array}{c}\left(\mathrm{X}_{\mathrm{i}}+\mathrm{X}_{\mathrm{i}+1}\right)^{2} \times \mathrm{H}_{\mathrm{i}} \\
\left(\times 10^{-7}\right)\end{array}$ & $\begin{array}{c}\left(\mathrm{H}-\mathrm{H}_{\mathrm{mi}}\right)^{2} \times \mathrm{H}_{\mathrm{i}} / \mathrm{V}_{\mathrm{s}, \mathrm{i}^{2}} \\
\left(\times 10^{-4}\right)\end{array}$ \\
\hline \multirow{6}{*}{ 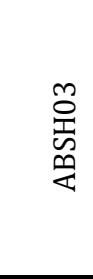 } & 1 & \multirow{3}{*}{$\stackrel{N}{\sim}$} & 6 & 3 & 9.00 & 640 & 1.318 & 1.042 & 11.865 \\
\hline & 2 & & 4 & 8 & 4.00 & 310 & 2.983 & 7.402 & 6.659 \\
\hline & 3 & & 2 & 11 & 1.00 & 100 & 4.983 & 12.693 & 2 \\
\hline & & & & & & & $\Sigma=$ & 21.13781 & 20.52496 \\
\hline & & & & & & & & $\omega(\mathrm{Hz})=$ & 62.321 \\
\hline & & & & & & & & $T(\mathrm{sec})=$ & 0.101 \\
\hline $\begin{array}{l}\text { Sta. } \\
\text { ID }\end{array}$ & $\begin{array}{l}\text { Layer } \\
\#\end{array}$ & $\begin{array}{c}\mathrm{H} \\
(\mathrm{m})\end{array}$ & $\begin{array}{l}\mathrm{H}_{\mathrm{i}} \\
(\mathrm{m})\end{array}$ & $\begin{array}{l}\mathrm{H}_{\mathrm{mi}} \\
(\mathrm{m})\end{array}$ & $\begin{array}{l}\mathrm{H}-\mathrm{H}_{\mathrm{mi}} \\
(\mathrm{m})\end{array}$ & $\begin{array}{c}V_{\mathrm{s}, \mathrm{i}} \\
(\mathrm{m} / \mathrm{s})\end{array}$ & $\begin{array}{c}X_{\mathrm{i}} \\
\left(\times 10^{-2}\right)\end{array}$ & $\begin{array}{c}\left(\mathrm{X}_{\mathrm{i}}+\mathrm{X}_{\mathrm{i}+1}\right)^{2} \times \mathrm{H}_{\mathrm{i}} \\
\left(\times 10^{-1}\right)\end{array}$ & $\begin{array}{c}\left(\mathrm{H}-\mathrm{H}_{\mathrm{mi}}\right)^{2} \times \mathrm{H}_{\mathrm{i}} / \mathrm{V}_{\mathrm{s}, \mathrm{i}}{ }^{2} \\
\left(\times 10^{0}\right)\end{array}$ \\
\hline \multirow{9}{*}{ 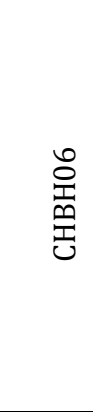 } & 1 & \multirow{6}{*}{$\underset{0}{\operatorname{L}}$} & 35.00 & 17.50 & 147.50 & 460 & 2.44 & 0.208 & 3.599 \\
\hline & 2 & & 38.00 & 54.00 & 111.00 & 440 & 4.619 & 1.893 & 2.418 \\
\hline & 3 & & 38.00 & 92.00 & 73.00 & 400 & 6.352 & 4.574 & 1.266 \\
\hline & 4 & & 36.00 & 129.00 & 36.00 & 360 & 7.352 & 6.761 & 0.36 \\
\hline & 5 & & 13.00 & 153.50 & 11.50 & 200 & 7.726 & 2.956 & 0.043 \\
\hline & 6 & & 5.00 & 162.50 & 2.50 & 180 & 776.45 & 1.2 & 0.001 \\
\hline & & & & & & & $\Sigma=$ & 17.592 & 7.687 \\
\hline & & & & & & & & $\omega(H z)=$ & 4.181 \\
\hline & & & & & & & & $T(\mathrm{sec})=$ & 1.503 \\
\hline
\end{tabular}

\subsection{Statistical Study}

Fundamental period values of 459 KiK-net stations are calculated by a fully-automatic MATLAB code which was developed in this study. The fully automatic algorithm calculates the true fundamental periods based on Simplified Rayleigh method, initially. Secondly, the predicted fundamental periods for each $i^{\text {th }}$ total travel time coefficient of average shear wave velocity are calculated. The difference of the true and predicted periods is nominated as the residuals. Henceforth, standard deviations of the residuals of $459 \mathrm{KiK}$-net data are calculated for each coefficient between 2.0 to 5.0 with 0.01 increments. The coefficient having the minimum standard deviation for residuals with highest correlation coefficients is considered to be the best-fit coefficient. Totally, $459 \times 301=138159$ calculations are performed in the content of this study. It is worth to note that in the mostly preferred equation by practitioners, the coefficient of the total travel time of shear wave was 4 , see Eq. (3).
Hereafter, relative difference (Rel. Dif.) for each data is calculated by Eq. (4) where $T_{\text {calculated }}$ and $T_{\text {true }}$ correspond to determined fundamental periods of the soil layers by different coefficients of Eq. (3) and Simplified Rayleigh method, Eq. (1c), respectively.

Rel. Dif. $=\frac{\left|T_{\text {calculated }}-T_{\text {true }}\right|}{T_{\text {true }}}$

Relative differences and their mean values of the original and proposed equations are also compared in the study.

\section{RESULTS}

Variation of the standard deviations of residuals with the coefficients for travel time of average shear wave (from bedrock to surface) is depicted in Figure 1. 

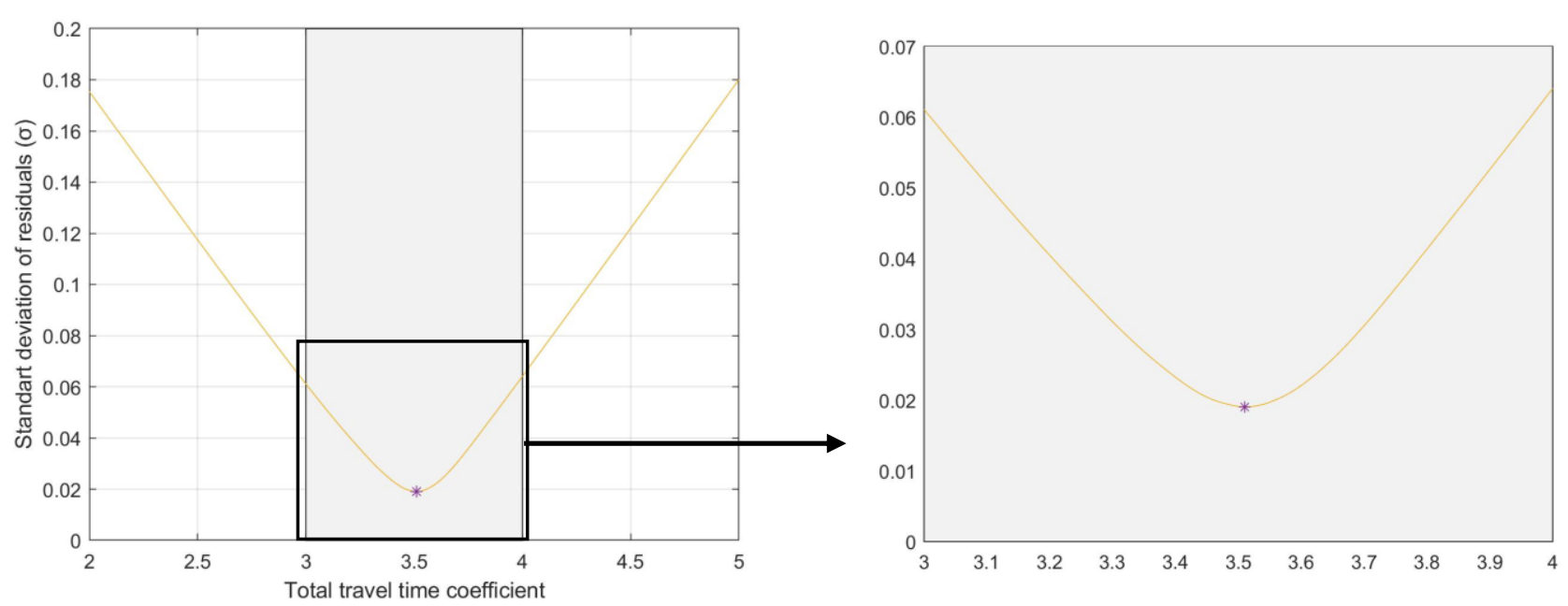

Figure 1. Variation of the standard deviation of the residuals for diverse total travel time coefficients of $V_{\text {avg }}$

The minimum standard deviation is obtained to be 0.019 for the coefficient of 3.51. Changing the coefficient of the equation simply with 3.51 will yield significantly lower standard deviation $(\sim \% 336)$ and increase the reliability of the equation.

Mean value and standard deviation of the residuals are given in Table 2 for the coefficients of 3.51 and the original value of 4.00 .

Table 2. Mean value and standard deviations of the residuals obtained by the proposed and original coefficients.

\begin{tabular}{lcc}
\hline Equation & Mean value & Standard deviation \\
\hline $3.51 \mathrm{H} / \mathrm{V}_{\mathrm{s}}$ & 0.0147 & 0.0191 \\
$4.00 \mathrm{H} / \mathrm{V}_{\mathrm{s}}$ & 0.0487 & 0.0641 \\
\hline
\end{tabular}

The correlation coefficient calculated for the true periods and the periods determined for the case of total travel time of shear velocity coefficient of 3.51 was found

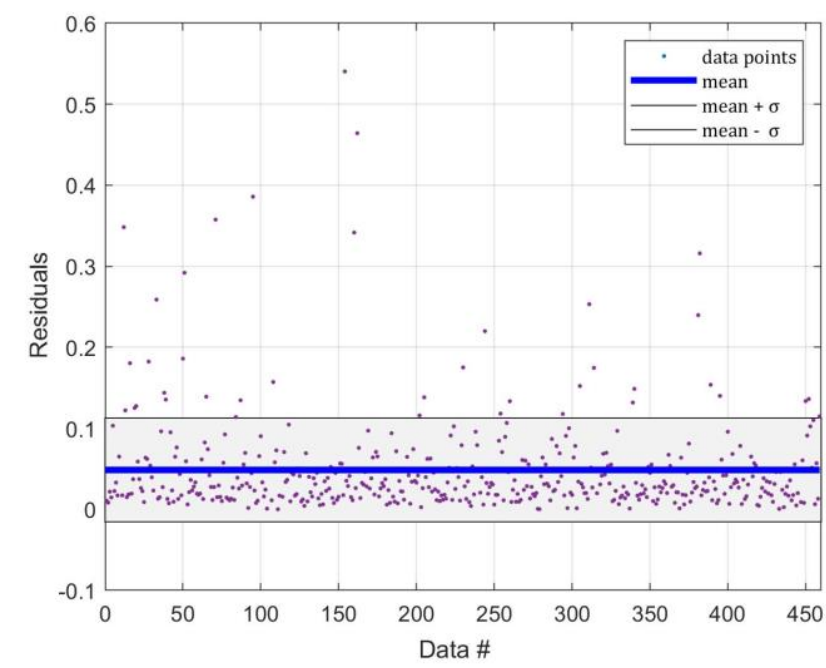

a- for Eq. (3)

Figure 2. Calculated absolute residuals

These statistical results show that the newly proposed equation, Eq. (5), provides better correlation with the true results. To be able to show the difference of proposed formula and the original one, relative to be 0.998 . The obtained correlation coefficient between the two series is extremely high. Therefore, Eq. (5) is proposed to determine fundamental periods of the layered soil profiles.

$\mathrm{T}=3.51 \frac{H}{V_{\text {avg }}}$

In the second step, absolute residuals of each data point are plotted for the coefficients of 3.51 and 4.00 in Figures $2 \mathrm{a}-\mathrm{b}$. In the figures, mean value \pm one standard deviation ranges are also depicted with gray color. Using the coefficient of 3.51 instead of 4.00 , considerably reduced the scattering area of the residuals. Additionally, highest absolute residuals are obtained as 0.12 for the proposed coefficient and 0.54 for the original coefficient of 4.00 .

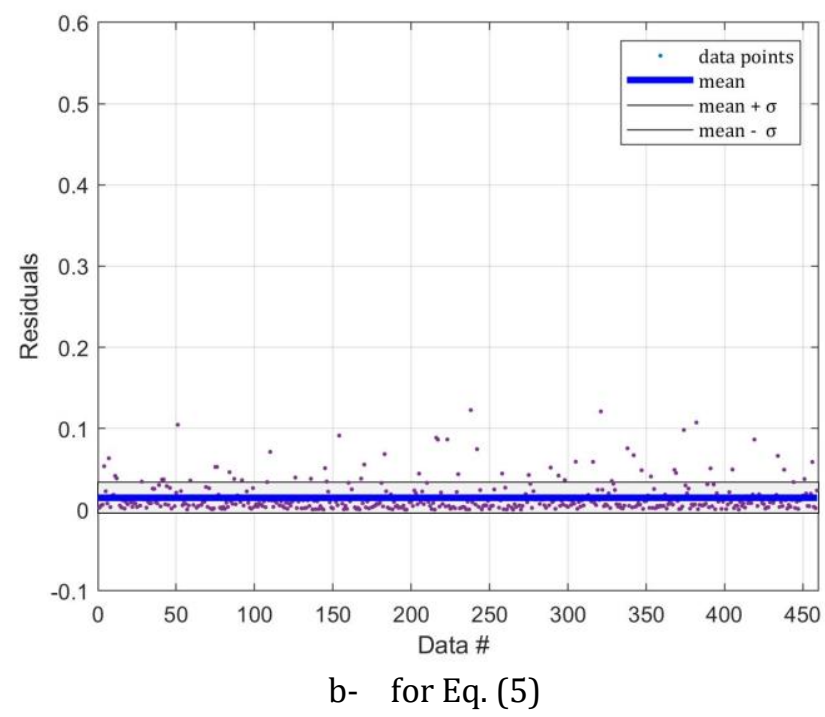

differences of Eqs. (3) and (5) with respect to Simplified Rayleigh method are illustrated for the all stations considered in this study, Figure 3. Average relative 
difference is reduced to almost $5 \%$ from $15 \%$ by using Eq. (5).

Finally, the predicted dominant periods are compared with the true ones in Figure 4. As it was expected, soft soils have longer fundamental periods

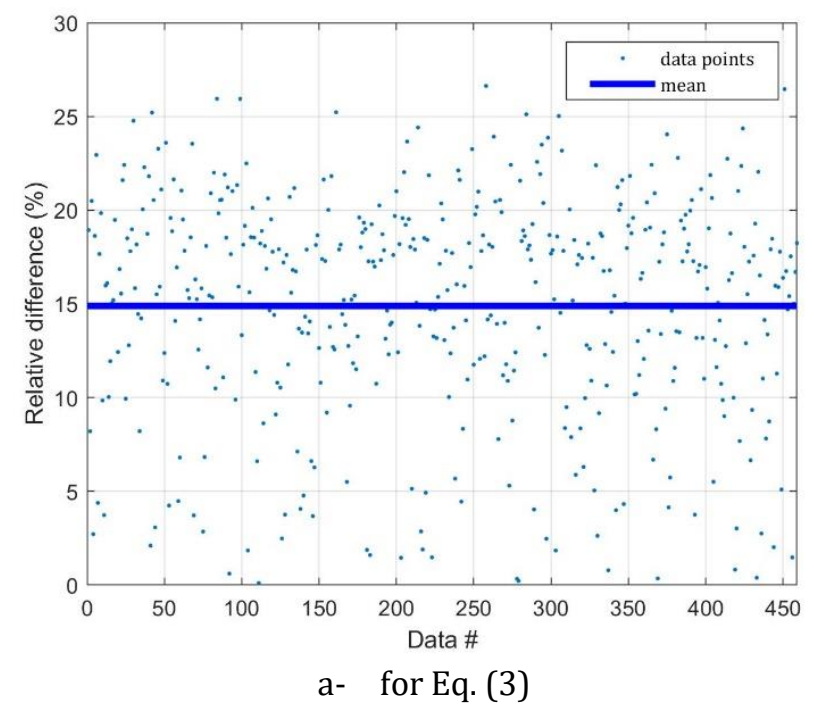

Figure 3. Calculated relative differences

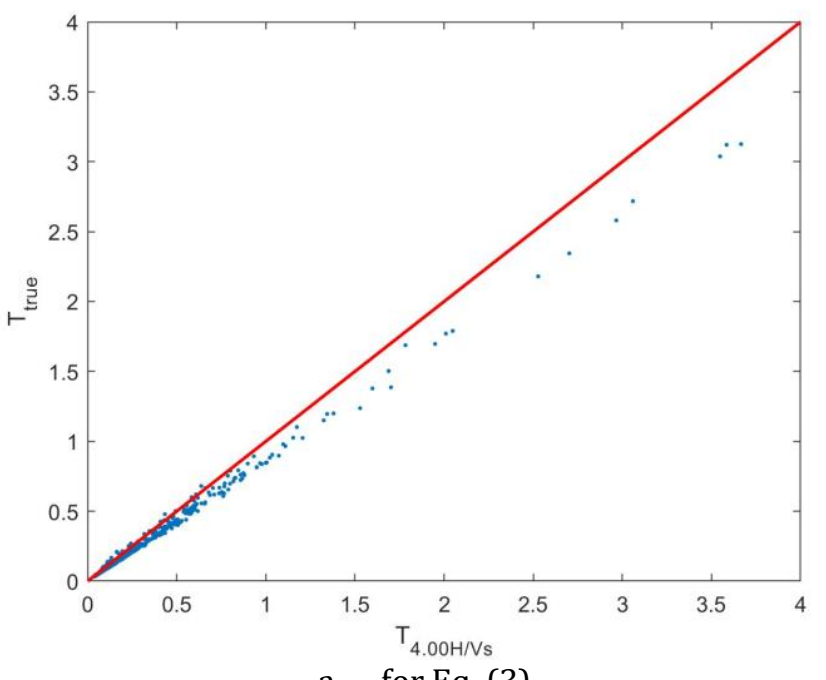

a- for Eq. (3) while the value is quite shorter for stiff soils. It is clear that the proposed equation has superior performance to capture true dominant period.
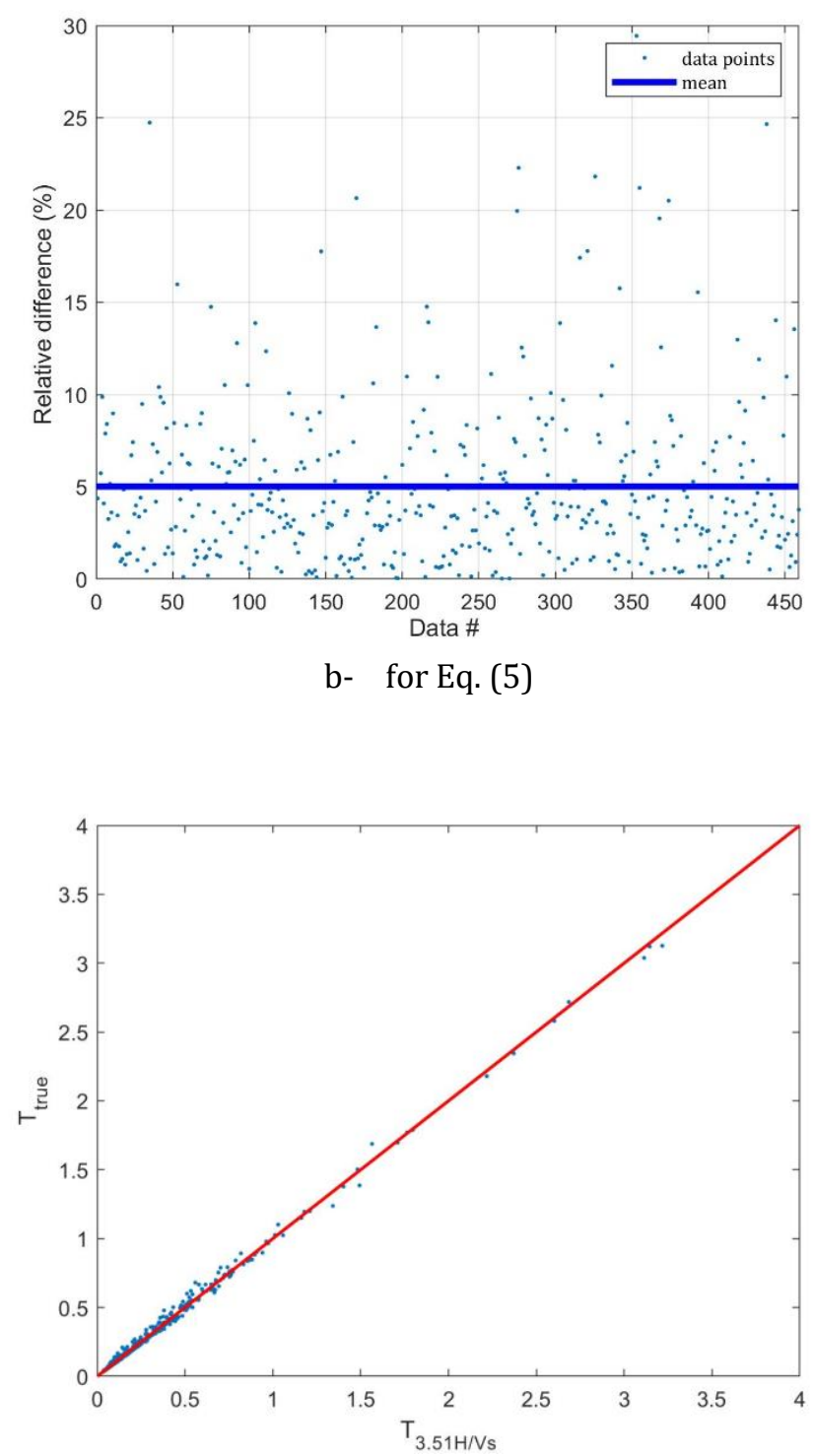

b- for Eq. (5)

Figure 4. Comparisons of the previous and the proposed equations with true period

Based on the performed statistical analyses, it can be said that the proposed equation, Eq. (5), yields more concrete results with similar simplicity.

\section{CONCLUSION}

Fundamental period of the layer soil profiles is a crucial parameter for the earthquake resistant design of structures and energy based seismic design. Due to the difficulty of applying numerical methods to the calculation of fundamental periods of soils, many simple formulas exist in the literature for practitioners. The roughest and the simplest equation, Eq. (3), is mostly preferred by the practitioners. Although this formula may give adequate results for some specific cases, it has a great standard deviation and approximately $15 \%$ error in average. In this study, a statistical study is applied to find out a better coefficient for total travel time $\left(H / V_{\text {avg }}\right)$ by utilizing the KiK-net database of Japan. The proposed formula gives better results with smaller standard deviation, higher correlation coefficient and it has only $5 \%$ mean relative difference with respect to true results. Moreover, the proposed equation has the same simplicity with the existing equation. Hence, using the proposed equation instead of the existing one is highly suggested. It is worth to remind that the study based on solely the KiK-net data. So, an amount of discrepancy may arise for some specific soil profiles which is not represented in this data set.

\section{ACKNOWLEDGEMENT}

The authors are so grateful to National Research Institute for Earth Science and Disaster Resilience (NIED)for providing the free access to KiK-net data. 
APPENDIX Soil data which is not utilized in the study

\begin{tabular}{|c|c|c|c|c|c|c|c|c|}
\hline Site Code & Site Name & Latitude & Longitude & Altitude (m) & Depth (m) & Prefecture & Seismo-graph & Notes \\
\hline ABSH02 & OKOРPE-W & 44.4234 & 143.0264 & 38 & 113 & HOKKAIDO & KiK-net06 & \\
\hline ABSH04 & TAKINOUE-N & 44.192 & 143.0767 & 134 & 200 & HOKKAIDO & KiK-net06 & \\
\hline ABSH11 & MEMAMBETSU & 43.9144 & 144.1913 & 40 & 122 & HOKKAIDO & KiK-net11B & \\
\hline ABSH12 & KOSHIMIZU & 43.8566 & 144.4574 & 25 & 120 & HOKKAIDO & KiK-net06 & \\
\hline AICH05 & TOKONAME & 34.8886 & 136.8763 & 50 & 401 & AICHIKEN & --- & suspension \\
\hline AICH13 & KIYOSU & 35.2177 & 136.8509 & 5 & 741 & AICHIKEN & KiK-net06 & \\
\hline AICH15 & ASUKE & 35.1392 & 137.3359 & 150 & 120 & AICHIKEN & KiK-net11B & \\
\hline АKTH02 & NISHIKI-S & 39.6634 & 140.5721 & 95 & 100 & AKITAKEN & KiK-net06 & \\
\hline АКTH03 & YAJIMA & 39.2223 & 140.1283 & 145 & 103 & AKITAKEN & KiK-net11A & \\
\hline АКTH05 & CHOKAI & 39.0718 & 140.3185 & 275 & 200 & AKITAKEN & KiK-net06 & \\
\hline АКTH07 & KOSAKA & 40.4563 & 140.8395 & 405 & 105 & AKITAKEN & KiK-net06 & \\
\hline АКТН09 & TASHIRO & 40.2755 & 140.4596 & 45 & 101 & AKITAKEN & KiK-net06 & \\
\hline AKTH10 & ODATE & 40.3002 & 140.5812 & 85 & 100 & AKITAKEN & KiK-net06 & \\
\hline АКTH16 & NISHISEMBOKU & 39.545 & 140.3481 & 20 & 154 & AKITAKEN & KiK-net06 & \\
\hline AKTH18 & OMORI & 39.3548 & 140.3869 & 65 & 100 & AKITAKEN & KiK-net06 & \\
\hline АОМН01 & OMA & 41.5273 & 140.9127 & 10 & 100 & AOMORIKEN & KiK-net06 & \\
\hline АОМН03 & KAWAUCHI & 41.234 & 140.9896 & 20 & 100 & AOMORIKEN & KiK-net11C & \\
\hline АОМН04 & AOMORI & 40.8524 & 140.6759 & 10 & 307 & AOMORIKEN & KiK-net06 & \\
\hline АОМН08 & AJIGASAWA & 40.7618 & 140.3121 & 50 & 160 & AOMORIKEN & KiK-net06 & \\
\hline АOMH11 & TOWADAKO-W & 40.58 & 140.995 & 240 & 100 & AOMORIKEN & KiK-net06 & \\
\hline АОМH12 & TOWADAKO-E & 40.5846 & 141.1547 & 85 & 100 & AOMORIKEN & KiK-net06 & \\
\hline АOMH13 & HACHINOHE & 40.5794 & 141.4451 & 10 & 150 & AOMORIKEN & KiK-net11C & \\
\hline АОМН16 & SHINGO & 40.4624 & 141.0923 & 315 & 150 & AOMORIKEN & KiK-net06 & \\
\hline CHBH04 & SHIMOSA & 35.7966 & 140.0206 & 23 & 2300 & CHIBAKEN & KiK-net06 & \\
\hline CHBH10 & CHIBA & 35.5458 & 140.2417 & 65 & 2000 & CHIBAKEN & KiK-net06 & \\
\hline СНBH11 & YORO & 35.2867 & 140.1529 & 80 & 2000 & CHIBAKEN & KiK-net06 & \\
\hline СHBH12 & FUTTSU & 35.3445 & 139.8554 & 3 & 2000 & CHIBAKEN & KiK-net11C & \\
\hline СНBH13 & NARITA & 35.8307 & 140.298 & 12 & 1300 & CHIBAKEN & KiK-net06 & \\
\hline СHBH14 & CHOSHI-C & 35.7342 & 140.823 & 2 & 525 & CHIBAKEN & KiK-net11A & \\
\hline СНBH15 & TATEYAMA-W & 34.9591 & 139.7885 & 30 & 500 & CHIBAKEN & KiK-net11A & \\
\hline СHBH19 & HASUNUMA & 35.5943 & 140.5107 & 1 & 1630 & CHIBAKEN & KiK-net06 & \\
\hline СHBH20 & KAMOGAWA-S & 35.0882 & 140.0997 & 28 & 306 & CHIBAKEN & KiK-net11B & \\
\hline ЕНMH01 & TSUSHIMA & 33.0556 & 132.5552 & 375 & 100 & EHIMEKEN & KiK-net11A & \\
\hline ЕHMH04 & TAMBARA & 33.9023 & 133.0658 & 15 & 200 & EHIMEKEN & KiK-net11A & \\
\hline EHMH12 & UWA & 33.427 & 132.5055 & 250 & 150 & EHIMEKEN & KiK-net11B & \\
\hline EHMH13 & MISAKI & 33.3719 & 132.1157 & 10 & 222 & EHIMEKEN & KiK-net18 & \\
\hline FKIH01 & EIHEIJI & 36.0955 & 136.3617 & 65 & 100 & FUKUIKEN & KiK-net06 & \\
\hline FKOH04 & КАНО & 33.5512 & 130.7451 & 60 & 100 & FUKUOKAKEN & KiK-net18 & \\
\hline FKOH05 & SAIGAWA & 33.5293 & 130.9503 & 370 & 100 & FUKUOKAKEN & KiK-net18 & \\
\hline FКОН06 & BUZEN & 33.5925 & 131.1348 & 35 & 303 & FUKUOKAKEN & KiK-net11C & \\
\hline FКОН10 & UKIHA & 33.2891 & 130.817 & 190 & 200 & FUKUOKAKEN & KiK-net11B & \\
\hline FKSH15 & INAWASHIRO & 37.6461 & 140.1735 & 757 & 100 & FUKUSHIMAKEN & KiK-net06 & \\
\hline FKSH16 & FUKUSHIMA & 37.7643 & 140.3766 & 135 & 300 & FUKUSHIMAKEN & KiK-net11A & \\
\hline FKSH17 & KAWAMATA & 37.6636 & 140.5974 & 205 & 100 & FUKUSHIMAKEN & KiK-net06 & \\
\hline FKSH20 & NAMIE & 37.4911 & 140.9871 & 12 & 109 & FUKUSHIMAKEN & KiK-net06 & \\
\hline GIFH04 & FURUKAWA & 36.2448 & 137.1983 & 572 & 100 & GIFUKEN & KiK-net11A & \\
\hline GIFH05 & SHOKAWA & 36.0654 & 136.9479 & 839 & 100 & GIFUKEN & KiK-net11A & \\
\hline GIFH14 & KAMITAKARA & 36.2493 & 137.5174 & 810 & 100 & GIFUKEN & KiK-net18 & \\
\hline
\end{tabular}


Turkish Journal of Engineering - 2022; 6(2); 95-105

\begin{tabular}{|c|c|c|c|c|c|c|c|}
\hline GIFH16 & ASAHI-N & 36.094 & 137.3438 & 790 & 100 & GIFUKEN & KiK-net18 \\
\hline GIFH18 & MAZE & 35.8991 & 137.1495 & 570 & 107 & GIFUKEN & KiK-net11A \\
\hline GIFH20 & GERO-N & 35.7991 & 137.2531 & 355 & 128 & GIFUKEN & KiK-net18 \\
\hline GIFH21 & MINAMI & 35.6665 & 136.9618 & 170 & 200 & GIFUKEN & KiK-net18 \\
\hline GIFH22 & KANAYAMA & 35.6682 & 137.1054 & 435 & 100 & GIFUKEN & KiK-net18 \\
\hline GNMH05 & ISESAKI & 36.3143 & 139.1847 & 57 & 2000 & GUNMAKEN & KiK-net11A \\
\hline GNMH06 & TATEBAYASHI & 36.2441 & 139.5443 & 20 & 1203 & GUNMAKEN & KiK-net06 \\
\hline GNMH07 & TONE & 36.6998 & 139.2104 & 646 & 200 & GUNMAKEN & KiK-net11B \\
\hline GNMH14 & MIDORI & 36.4931 & 139.3219 & 360 & 200 & GUNMAKEN & KiK-net11A \\
\hline HDKH03 & MOMBETSU-E & 42.5934 & 142.3521 & 160 & 106 & HOKKAIDO & KiK-net06 \\
\hline HRSH03 & MITSUGI & 34.5183 & 133.1375 & 160 & 200 & HIROSHIMAKEN & KiK-net11A \\
\hline HRSH04 & NUMAKUMA & 34.3785 & 133.3493 & 25 & 200 & HIROSHIMAKEN & KiK-net11A \\
\hline HRSH12 & HIROSHIMA & 34.581 & 132.4295 & 360 & 150 & HIROSHIMAKEN & KiK-net11C \\
\hline HRSH17 & TOGOUCHI & 34.5716 & 132.2326 & 265 & 102 & HIROSHIMAKEN & KiK-net11C \\
\hline IBRH06 & KITAIBARAKI2 & 36.8809 & 140.6545 & 395 & 100 & IBARAKIKEN & KiK-net11 \\
\hline IBRH07 & EDOSAKI & 35.9521 & 140.3301 & 3 & 1200 & IBARAKIKEN & KiK-net11A \\
\hline IBRH08 & TAIYO & 36.1188 & 140.5621 & 40 & 1200 & IBARAKIKEN & KiK-net06 \\
\hline IBRH09 & ЈОНОКU & 36.439 & 140.3559 & 50 & 106 & IBARAKIKEN & KiK-net11C \\
\hline IBRH15 & GOZENYAMA & 36.5566 & 140.3013 & 45 & 107 & IBARAKIKEN & KiK-net11B \\
\hline IBRH19 & TSUKUBA & 36.2137 & 140.0893 & 175 & 210 & IBARAKIKEN & KiK-net06 \\
\hline IBRH21 & TSUKUBA-S & 35.9814 & 140.105 & 22 & 929 & IBARAKIKEN & KiK-net06 \\
\hline IBUH03 & ATSUMA & 42.6486 & 141.8641 & 10 & 153 & HOKKAIDO & KiK-net06 \\
\hline IKRH02 & SHINSHINOTSU & 43.2204 & 141.6523 & 10 & 127 & HOKKAIDO & KiK-net06 \\
\hline ISKH01 & SUZU & 37.5266 & 137.2844 & 48 & 200 & ISHIKAWAKEN & KiK-net06 \\
\hline ISKH02 & YANAGIDA & 37.3644 & 137.0413 & 121 & 102 & ISHIKAWAKEN & KiK-net11C \\
\hline ISKH06 & SHIKA & 37.0533 & 136.8206 & 20 & 200 & ISHIKAWAKEN & KiK-net11A \\
\hline IWTH03 & IWAIZUMI & 39.802 & 141.652 & 310 & 100 & IWATEKEN & KiK-net11C \\
\hline IWTH06 & NINOHE-W & 40.2611 & 141.1709 & 225 & 100 & IWATEKEN & KiK-net06 \\
\hline IWTH07 & KARUMAI & 40.2705 & 141.5709 & 260 & 120 & IWATEKEN & KiK-net06 \\
\hline IWTH09 & KUJI-S & 40.0861 & 141.712 & 240 & 100 & IWATEKEN & KiK-net06 \\
\hline IWTH15 & YAHABA & 39.6148 & 141.0929 & 195 & 122 & IWATEKEN & KiK-net06 \\
\hline IWTH17 & KAWAI-N & 39.6442 & 141.5977 & 305 & 103 & IWATEKEN & KiK-net11C \\
\hline IWTH20 & HANAMAKI-S & 39.3434 & 141.0473 & 106 & 156 & IWATEKEN & KiK-net11C \\
\hline IWTH24 & KANEGASAKI & 39.1979 & 141.0118 & 200 & 150 & IWATEKEN & KiK-net11C \\
\hline IWTH26 & ICHINOSEKI-E & 38.969 & 141.0013 & 125 & 108 & IWATEKEN & KiK-net11C \\
\hline IWTH27 & RIKUZENTAKATA & 39.0307 & 141.532 & 80 & 100 & IWATEKEN & KiK-net11C \\
\hline KGSH03 & MIYANOJO & 31.9812 & 130.4438 & 110 & 100 & KAGOSHIMAKEN & KiK-net06 \\
\hline KGSH04 & SENDAI & 31.8374 & 130.3602 & 14 & 100 & KAGOSHIMAKEN & KiK-net11C \\
\hline KGSH05 & KEDOIN & 31.8699 & 130.4958 & 73 & 107 & KAGOSHIMAKEN & KiK-net06 \\
\hline KGSH06 & KORIYAMA & 31.6988 & 130.4594 & 131 & 203 & KAGOSHIMAKEN & KiK-net06 \\
\hline KGSH07 & AIRA & 31.714 & 130.6149 & 6 & 302 & KAGOSHIMAKEN & KiK-net11C \\
\hline KGSH08 & OHSUMI & 31.5618 & 130.9969 & 97 & 150 & KAGOSHIMAKEN & KiK-net06 \\
\hline KGSH13 & KANOYA & 31.4005 & 130.8541 & 40 & 101 & KAGOSHIMAKEN & KiK-net06 \\
\hline KGWH03 & MIKI & 34.27 & 134.1482 & 50 & 100 & KAGAWAKEN & KiK-net11A \\
\hline KGWH05 & UCHINOMI & 34.4572 & 134.3241 & 20 & 433 & KAGAWAKEN & KiK-net11B \\
\hline KKWH01 & BIFUKA-N & 44.5973 & 142.3036 & 61 & 111 & HOKKAIDO & KiK-net06 \\
\hline KKWH03 & BIFUKA-W & 44.4732 & 142.2725 & 100 & 100 & HOKKAIDO & KiK-net06 \\
\hline KKWH04 & NAYORO & 44.4376 & 142.4056 & 84 & 100 & HOKKAIDO & KiK-net06 \\
\hline KKWH05 & SHIMOKAWA-W & 44.2921 & 142.6303 & 160 & 300 & HOKKAIDO & KiK-net06 \\
\hline KKWH06 & SHIMOKAWA-E & 44.3207 & 142.7656 & 200 & 100 & HOKKAIDO & KiK-net06 \\
\hline KKWH12 & BIEI-E & 43.5038 & 142.6006 & 450 & 207 & HOKKAIDO & KiK-net11B \\
\hline
\end{tabular}




\begin{tabular}{|c|c|c|c|c|c|c|c|c|}
\hline KMMH04 & ASO & 32.9514 & 131.0199 & 475 & 127 & KUMAMOTOKEN & --- & suspension \\
\hline КМMH07 & MISUMI & 32.6234 & 130.5584 & 22 & 300 & KUMAMOTOKEN & KiK-net11B & \\
\hline KMMH11 & ASHIKITA & 32.2918 & 130.5777 & 100 & 300 & KUMAMOTOKEN & KiK-net11B & \\
\hline КМMH17 & TAMANA & 32.9873 & 130.5608 & 55 & 100 & KUMAMOTOKEN & KiK-net11B & \\
\hline KMMH18 & ASO2 & 33.0031 & 131.0071 & 932 & 78 & KUMAMOTOKEN & KiK-net11B & \\
\hline KNGH10 & ҮОКОНАМА & 35.4991 & 139.5195 & 62 & 2000 & KANAGAWAKEN & KiK-net06 & \\
\hline KNGH11 & ATSUGI & 35.404 & 139.3539 & 12 & 1800 & KANAGAWAKEN & KiK-net06 & \\
\hline KNGH21 & KIYOKAWA & 35.4628 & 139.2146 & 455 & 210 & KANAGAWAKEN & KiK-net11A & \\
\hline КОСН02 & GOHOKU & 33.7079 & 133.3641 & 590 & 100 & KOCHIKEN & KiK-net11A & \\
\hline КОСH04 & OTSUKI & 32.8414 & 132.7066 & 55 & 100 & KOCHIKEN & KiK-net11A & \\
\hline КоСН05 & IKEKAWA & 33.6472 & 133.1444 & 260 & 100 & KOCHIKEN & KiK-net11A & \\
\hline КоСH06 & NAKAMURA & 33.0754 & 132.9524 & 31 & 100 & KOCHIKEN & KiK-net11A & \\
\hline КОСН09 & КАНОKU & 33.6748 & 133.8243 & 190 & 100 & KOCHIKEN & KiK-net11B & \\
\hline КосH11 & MUROTO & 33.2866 & 134.1603 & 90 & 300 & KOCHIKEN & KiK-net11B & \\
\hline KSRH01 & AKAN-N & 43.4361 & 144.0844 & 431 & 106 & HOKKAIDO & KiK-net11B & \\
\hline KSRH02 & AKAN-S & 43.1142 & 144.123 & 30 & 105 & HOKKAIDO & KiK-net06 & \\
\hline KSRH03 & SHIBECHA-N & 43.3848 & 144.6279 & 83 & 107 & HOKKAIDO & KiK-net06 & \\
\hline KSRH04 & SHIBECHA-S & 43.2139 & 144.6804 & 30 & 240 & HOKKAIDO & KiK-net11A & \\
\hline KSRH06 & TSURUI-E & 43.22 & 144.4285 & 30 & 237 & HOKKAIDO & KiK-net06 & \\
\hline KSRH07 & TSURUI-S & 43.1359 & 144.3274 & 38 & 222 & HOKKAIDO & KiK-net11B & \\
\hline KSRH08 & SHIRANUKA-N & 43.1603 & 143.8936 & 174 & 100 & HOKKAIDO & KiK-net06 & \\
\hline KSRH09 & SHIRANUKA-S & 42.9856 & 143.9841 & 27 & 100 & HOKKAIDO & KiK-net06 & \\
\hline KSRH10 & HAMANAKA & 43.2084 & 145.1168 & 31 & 255 & HOKKAIDO & KiK-net11B & \\
\hline KYTH04 & MIYAMA & 35.2685 & 135.5508 & 190 & 100 & KYOTOFU & KiK-net18 & \\
\hline КYТH07 & KUMIYAMA & 34.8983 & 135.7461 & 11 & 800 & KYOTOFU & KiK-net18 & \\
\hline MIEH08 & MATSUSAKA & 34.5424 & 136.5033 & 35 & 150 & MIEKEN & KiK-net11B & \\
\hline MYGH04 & TOWA & 38.786 & 141.3254 & 35 & 100 & MIYAGIKEN & KiK-net06 & \\
\hline MYGH07 & KAWASAKI & 38.1802 & 140.6405 & 186 & 142 & MIYAGIKEN & KiK-net11 & \\
\hline MYGH08 & IWANUMA & 38.1133 & 140.8441 & 10 & 100 & MIYAGIKEN & KiK-net11C & \\
\hline MYGH12 & SHIZUGAWA & 38.6416 & 141.4428 & 18 & 102 & MIYAGIKEN & --- & suspension \\
\hline MYGH14 & RIFU & 38.34 & 140.9551 & 48 & 1034 & MIYAGIKEN & KiK-net11 & \\
\hline MYZH05 & NANGO & 32.347 & 131.2668 & 353 & 100 & MIYAZAKIKEN & KiK-net06 & \\
\hline MYZH06 & TOGO & 32.3607 & 131.4643 & 100 & 100 & MIYAZAKIKEN & KiK-net11C & \\
\hline MYZH09 & SUKI & 32.0421 & 131.0618 & 335 & 100 & MIYAZAKIKEN & KiK-net11C & \\
\hline MYZH16 & NOBEOKA & 32.506 & 131.6958 & 2 & 100 & MIYAZAKIKEN & KiK-net06 & \\
\hline NARH02 & TOTSUKAWA-E & 33.9692 & 135.8574 & 480 & 100 & NARAKEN & KiK-net11A & \\
\hline NARH06 & YAMAZOE & 34.6413 & 136.0512 & 277 & 101 & NARAKEN & KiK-net11A & \\
\hline NGNH07 & NAKANO & 36.7434 & 138.376 & 378 & 200 & NAGANOKEN & KiK-net06 & \\
\hline NGNH09 & TAKESHI & 36.2859 & 138.2491 & 605 & 100 & NAGANOKEN & KiK-net06 & \\
\hline NGNH12 & MINAMIMAKI & 35.9696 & 138.4797 & 1320 & 206 & NAGANOKEN & KiK-net06 & \\
\hline NGNH22 & HASE & 35.7946 & 138.0824 & 820 & 100 & NAGANOKEN & KiK-net06 & \\
\hline NGNH27 & SHINSHUSHIN & 36.577 & 138.0479 & 505 & 102 & NAGANOKEN & KiK-net06 & \\
\hline NGNH34 & OHMACHI-C & 36.5327 & 137.8201 & 825 & 106 & NAGANOKEN & KiK-net06 & \\
\hline NGNH54 & IIDA & 35.4489 & 138.0058 & 1168 & 104 & NAGANOKEN & KiK-net06 & \\
\hline NGSH02 & SASEBO-N & 33.2122 & 129.7652 & 140 & 112 & NAGASAKIKEN & KiK-net18 & \\
\hline NGSH06 & NAGASAKI & 32.6999 & 129.8625 & 155 & 200 & NAGASAKIKEN & KiK-net18 & \\
\hline NIGH01 & NAGAOKA & 37.4272 & 138.8876 & 85 & 100 & NIIGATAKEN & KiK-net11A & \\
\hline NIGH02 & ASAHI & 38.2799 & 139.5486 & 34 & 104 & NIIGATAKEN & KiK-net06 & \\
\hline NIGH03 & ARAKAWA & 38.1327 & 139.4289 & 6 & 221 & NIIGATAKEN & KiK-net06 & \\
\hline NIGH04 & SEKIKAWA & 38.1313 & 139.5428 & 78 & 100 & NIIGATAKEN & KiK-net06 & \\
\hline NIGH05 & SEIRO & 37.9759 & 139.2788 & 7 & 147 & NIIGATAKEN & KiK-net06 & \\
\hline
\end{tabular}




\begin{tabular}{|c|c|c|c|c|c|c|c|}
\hline NIGH06 & KAMO & 37.6527 & 139.0676 & 30 & 100 & NIIGATAKEN & KiK-net06 \\
\hline NIGH15 & MUIKA & 37.0533 & 138.9951 & 358 & 100 & NIIGATAKEN & KiK-net06 \\
\hline NIGH19 & YUZAWA & 36.8114 & 138.7849 & 985 & 100 & NIIGATAKEN & KiK-net11C \\
\hline NMRH03 & NAKASHIBETSU & 43.5508 & 144.9665 & 30 & 228 & HOKKAIDO & KiK-net11B \\
\hline NMRH04 & BEKKAI-E & 43.3978 & 145.1224 & 30 & 216 & HOKKAIDO & KiK-net11A \\
\hline NMRH05 & BEKKAI-W & 43.39 & 144.8021 & 92 & 220 & HOKKAIDO & KiK-net06 \\
\hline ОITH01 & YAMAGUNI & 33.4122 & 131.0326 & 249 & 200 & OITAKEN & KiK-net11B \\
\hline ОIтH02 & YAMAGA & 33.4581 & 131.4429 & 165 & 100 & OITAKEN & KiK-net11B \\
\hline ОІтн05 & NOTSUHARA & 33.1525 & 131.542 & 160 & 100 & OITAKEN & KiK-net11B \\
\hline OITH06 & TAKETA & 32.9726 & 131.3984 & 260 & 103 & OITAKEN & KiK-net11B \\
\hline оІтн09 & UME-E & 32.8486 & 131.6786 & 190 & 100 & OITAKEN & KiK-net06 \\
\hline ОКYH02 & SETO & 34.7501 & 134.0702 & 30 & 200 & OKAYAMAKEN & KiK-net11A \\
\hline ОКҮH07 & SHINGO & 35.0493 & 133.3169 & 564 & 100 & OKAYAMAKEN & KiK-net18 \\
\hline OKYH10 & KAMISAIBARA & 35.2826 & 133.9263 & 495 & 200 & OKAYAMAKEN & KiK-net11A \\
\hline OKYH11 & SHOO & 35.0732 & 134.1162 & 129 & 200 & OKAYAMAKEN & KiK-net11A \\
\hline OKYH12 & OHARA & 35.0999 & 134.319 & 280 & 200 & OKAYAMAKEN & KiK-net11A \\
\hline ОКYH13 & HINASE & 34.7283 & 134.2744 & 3 & 103 & OKAYAMAKEN & KiK-net18 \\
\hline ОКYH14 & HOKUBO & 34.9363 & 133.6205 & 218 & 100 & OKAYAMAKEN & KiK-net18 \\
\hline OSKH01 & TAJIRI & 34.3977 & 135.2836 & 5 & 1505 & OSAKAFU & KiK-net06 \\
\hline OSKH02 & KONOHANA & 34.6628 & 135.3896 & 7 & 2008 & OSAKAFU & KiK-net11A \\
\hline RMIH01 & HORONOBE & 45.0167 & 142.0795 & 30 & 100 & HOKKAIDO & KiK-net06 \\
\hline RMIH02 & TESHIO & 44.8948 & 141.9251 & 10 & 107 & HOKKAIDO & KiK-net06 \\
\hline RMIH03 & EMBETSU & 44.6359 & 141.8187 & 20 & 209 & HOKKAIDO & KiK-net06 \\
\hline SAGH05 & SHIROISHI & 33.1806 & 130.1046 & 18 & 203 & SAGAKEN & KiK-net18 \\
\hline SBSH01 & FURUBIRA & 43.2341 & 140.6228 & 28 & 100 & HOKKAIDO & KiK-net06 \\
\hline SBSH02 & TOMARI & 43.0527 & 140.5017 & 25 & 100 & HOKKAIDO & KiK-net06 \\
\hline SBSH03 & AKAIGAWA & 43.0842 & 140.8199 & 145 & 220 & HOKKAIDO & KiK-net11B \\
\hline SBSH 04 & KYOWA & 42.9758 & 140.6219 & 20 & 200 & HOKKAIDO & KiK-net06 \\
\hline SBSH05 & KUCCHAN & 42.95 & 140.8223 & 240 & 100 & HOKKAIDO & KiK-net06 \\
\hline SBSH06 & RANKOSHI & 42.8309 & 140.4831 & 39 & 130 & HOKKAIDO & KiK-net06 \\
\hline SBSH07 & MAKKARI & 42.763 & 140.8084 & 228 & 100 & HOKKAIDO & KiK-net06 \\
\hline SBSH10 & SHIMAMAKI & 42.7797 & 140.1557 & 32 & 100 & HOKKAIDO & KiK-net11B \\
\hline SIGH01 & TAGA & 35.2383 & 136.3599 & 610 & 100 & SHIGAKEN & KiK-net06 \\
\hline SIGH02 & OHTSU & 35.2482 & 135.8671 & 305 & 100 & SHIGAKEN & KiK-net11A \\
\hline SITH01 & IWATSUKI & 35.929 & 139.7349 & 8 & 3510 & SAITAMAKEN & KiK-net11A \\
\hline SITH03 & HIDAKA & 35.899 & 139.3843 & 51 & 1800 & SAITAMAKEN & KiK-net06 \\
\hline SITH04 & TOKOROZAWA & 35.8028 & 139.5353 & 30 & 2000 & SAITAMAKEN & KiK-net06 \\
\hline SITH05 & KAMIIZUMI & 36.1509 & 139.0504 & 150 & 100 & SAITAMAKEN & KiK-net11A \\
\hline SMNH10 & MIHONOSEKI & 35.5579 & 133.3004 & 9 & 200 & SHIMANEKEN & KiK-net06 \\
\hline SMNH12 & YOSHIDA & 35.1634 & 132.8558 & 380 & 101 & SHIMANEKEN & KiK-net06 \\
\hline SMNH14 & MUIKAMACHI & 34.3904 & 131.8925 & 249 & 100 & SHIMANEKEN & KiK-net06 \\
\hline SOYH02 & SARUFUTSU-S & 45.2163 & 142.2254 & 5 & 100 & HOKKAIDO & KiK-net06 \\
\hline SOYH03 & WAKKANAI-W & 45.2531 & 141.6334 & 8 & 137 & HOKKAIDO & KiK-net06 \\
\hline SOYH04 & WAKKANAI-E & 45.2303 & 141.8806 & 30 & 203 & HOKKAIDO & KiK-net06 \\
\hline SOYH06 & тоуотомі & 45.1019 & 141.7834 & 15 & 135 & HOKKAIDO & KiK-net11A \\
\hline SRCH03 & HOROKANAI-S & 43.9994 & 142.1258 & 155 & 100 & HOKKAIDO & KiK-net06 \\
\hline SRCH04 & NUMATA & 43.8203 & 141.9397 & 100 & 105 & HOKKAIDO & KiK-net06 \\
\hline SRCH08 & SUNAGAWA & 43.5138 & 141.909 & 30 & 122 & HOKKAIDO & KiK-net06 \\
\hline SRCH09 & KURIYAMA & 43.0587 & 141.8063 & 30 & 122 & HOKKAIDO & KiK-net06 \\
\hline SRCH10 & YUBARI & 42.993 & 142.0085 & 195 & 200 & HOKKAIDO & KiK-net06 \\
\hline $\mathrm{SZOH} 24$ & INASA & 34.8343 & 137.6616 & 19 & 300 & SHIZUOKAKEN & KiK-net11B \\
\hline
\end{tabular}


Turkish Journal of Engineering - 2022; 6(2); 95-105

\begin{tabular}{|c|c|c|c|c|c|c|c|}
\hline $\mathrm{SZOH} 26$ & FUKUROI & 34.7948 & 137.9034 & 23 & 450 & SHIZUOKAKEN & KiK-net06 \\
\hline SZOH41 & MINAMIIZU & 34.6749 & 138.834 & 60 & 109 & SHIZUOKAKEN & KiK-net06 \\
\hline SZOH53 & KAKEGAWA3 & 34.8768 & 138.0174 & 182 & 100 & SHIZUOKA KEN & KiK-net11B \\
\hline SZOH54 & HATSUSHIMA2 & 35.0417 & 139.1685 & 20 & 110 & SHIZUOKA KEN & KiK-net06 \\
\hline TCGH06 & MOKA & 36.4458 & 139.9509 & 70 & 1648 & TOCHIGIKEN & KiK-net06 \\
\hline TCGH08 & KURIYAMA-E & 36.8828 & 139.6459 & 702 & 203 & TOCHIGIKEN & KiK-net11A \\
\hline TCGH11 & IMAICHI & 36.7084 & 139.7694 & 290 & 200 & TOCHIGIKEN & KiK-net11A \\
\hline TCGH13 & BATO & 36.7342 & 140.1781 & 135 & 140 & TOCHIGIKEN & KiK-net11C \\
\hline TCGH16 & HAGA & 36.548 & 140.0751 & 105 & 112 & TOCHIGIKEN & KiK-net11A \\
\hline TCGH17 & FUJIHARA2 & 36.9853 & 139.6922 & 635 & 104 & TOCHIGIKEN & KiK-net06 \\
\hline TKCH06 & MEMURO & 42.892 & 143.0603 & 97 & 227 & HOKKAIDO & KiK-net06 \\
\hline ТКСН07 & TOYOKORO & 42.8114 & 143.5203 & 9 & 100 & HOKKAIDO & KiK-net06 \\
\hline TKSH02 & SADAMITSU & 34.0112 & 134.0918 & 190 & 100 & TOKUSHIMAKEN & KiK-net11A \\
\hline TKSH03 & KOYADAIRA & 33.8778 & 134.1294 & 640 & 201 & TOKUSHIMAKEN & KiK-net11A \\
\hline TKYH02 & FUCHU & 35.6539 & 139.4704 & 45 & 2753 & тОКҮОто & KiK-net06 \\
\hline TKYH11 & КОТО & 35.6114 & 139.8125 & 6 & 3000 & тОКҮОто & KiK-net11A \\
\hline TKYH13 & HINOHARA-S & 35.7017 & 139.1275 & 360 & 100 & токуото & KiK-net11B \\
\hline TYMH02 & DAIMON & 36.7142 & 137.0378 & 5 & 212 & TOYAMAKEN & KiK-net06 \\
\hline ТYМH03 & TOYAMA & 36.7294 & 137.2627 & 8 & 580 & TOYAMAKEN & KiK-net06 \\
\hline TYMH04 & UOZU & 36.7914 & 137.4689 & 154 & 100 & TOYAMAKEN & KiK-net06 \\
\hline TYMH06 & YATSUO & 36.5711 & 137.1595 & 110 & 200 & TOYAMAKEN & KiK-net06 \\
\hline WKYH04 & SUSAMI & 33.5559 & 135.5454 & 130 & 100 & WAKAYAMAKEN & KiK-net11A \\
\hline WKYH06 & ото & 33.6948 & 135.5953 & 218 & 100 & WAKAYAMAKEN & KiK-net11A \\
\hline YMGH01 & HOFU & 34.0494 & 131.5618 & 35 & 200 & YAMAGUCHIKEN & KiK-net11A \\
\hline YMGH06 & UBE & 33.9893 & 131.3012 & 80 & 200 & YAMAGUCHIKEN & KiK-net11A \\
\hline YMGH12 & MITO & 34.2176 & 131.3597 & 150 & 102 & YAMAGUCHIKEN & KiK-net06 \\
\hline YMGH16 & KAMINOSEKI & 33.826 & 132.104 & 65 & 106 & YAMAGUCHIKEN & KiK-net06 \\
\hline YMNH08 & NISHINOHARA & 35.6895 & 138.734 & 375 & 1206 & YAMANASHIKEN & KiK-net06 \\
\hline YMNH10 & HAYAKAWA-N & 35.5351 & 138.3087 & 695 & 107 & YAMANASHIKEN & KiK-net11A \\
\hline YMNH13 & MINOBU & 35.3509 & 138.4203 & 255 & 204 & YAMANASHIKEN & KiK-net11A \\
\hline YMNH14 & TSURU-S & 35.5115 & 138.9675 & 1010 & 250 & YAMANASHIKEN & KiK-net11A \\
\hline YMNH15 & KAMIKUISHIKI & 35.5323 & 138.6045 & 525 & 116 & YAMANASHIKEN & KiK-net11A \\
\hline YMNH16 & KOFU2 & 35.7421 & 138.5653 & 595 & 256 & YAMANASHIKEN & KiK-net06 \\
\hline YMTH01 & TENDO & 38.3841 & 140.3805 & 113 & 207 & YAMAGATAKEN & KiK-net11A \\
\hline YMTH02 & YAMAGATA & 38.2693 & 140.2583 & 130 & 150 & YAMAGATAKEN & KiK-net11A \\
\hline YMTH03 & NANYO & 38.1035 & 140.1553 & 278 & 114 & YAMAGATAKEN & KiK-net11A \\
\hline YMTH08 & YAWATA & 38.9701 & 140.0333 & 115 & 106 & YAMAGATAKEN & KiK-net11A \\
\hline YMTH14 & NISHIKAWA-W & 38.386 & 139.9916 & 465 & 103 & YAMAGATAKEN & KiK-net11C \\
\hline
\end{tabular}




\section{Author Contributions}

Serkan Hasanoğlu: Development and application of MATLAB codes, writing, editing; Ahmet Güllü: Conceptualize, development of algorithms, evaluating the results, writing, editing.

\section{Conflict of interest}

The authors declare that there is no known conflict of interest.

\section{REFERENCES}

Dobry R, Oweis I \& Urzua A (1976). Simplified procedures for estimating the fundamental period of a soil profile. Bulletin of Seismological Society of America 66:1293-1321.

Gazetas G (1982). Vibrational characteristics of soil deposits with variable wave velocity. Int. J. Numer. Anal. Methods Geomech. 6, 1-20, doi:10.1002/nag.1610060103.

Ghofrani H, Atkinson G M, \& Goda K (2013). Implications of the 2011 M9.0 Tohoku Japan earthquake for the treatment of site effects in large earthquakes. Bull. Seismol. Soc. Am. 11, 171-203, doi:10.1007/s10518-012-9413-4.

Goda K, Kiyota T, Pokhrel RM, Chiaro G, Katagiri T, Sharma K \& Wilkinson S (2015). The 2015 Gorkha Nepal earthquake: insights from earthquake damage survey, Frontiers in Built Environment, 1, 18. https://doi.org/10.3389/fbuil.2015.00008.

Güllü A, Yüksel E, Yalçın C, Dindar A A, Özkaynak H, Büyüköztürk O (2019). An improved input energy spectrum verified by shake table tests. Earthq. Eng. Struct. Dynam. 48(1), 27-45. doi: 10.1002/eqe.3121

Hadjian A H (2002). Fundamental period and mode shape of layered soil profiles. Soil. Dynam. Earthq. Eng. 22, 885-891. doi: 10.1016/S02677261(02)00111-2.

National Research Institute for Earth Science and Disaster (2019). NIED K-NET, KiK-net, National Research Institute for Earth Science and Disaster Resilience. doi:10.17598/NIED.0004.

Madera G A (1970). Fundamental Period and Amplification of Peak Acceleration in Layered
Systems. Research Report R70-37, Dept. of Civil Engineering, MJ.T., Cambridge, Mass.

Mathworks Inc, MATLAB available at www.mathworks.com.

Sextos A, De Risi R, Pagliaroli A et al (2018), Local site effects and internal damage of buildings during the 2016 central Italy earthquake sequence, Earthquake Spectra, 34(4), 1639-1669. https://doi.org/10.1193/100317EQS194M.

Urzua A, Dobry R \& Christian J (2017). Is harmonic averaging of shear wave velocity or the simplified Rayleigh method appropriate to estimate the period of a soil profile. Earthq. Spectra 33, 895-915. doi:10.1193/101716EQS174M.

Vijayendra K V, Nayak S \& Prasad S K (2014). An Alternative Method to Estimate Fundamental Period of Layered Soil Deposit, Indian Geotech J. doi: 10.1007/s40098-014-0121-7

Wang S, Shi Y, Jiang W, Yao E \& Miao Y (2018). Estimating Site Fundamental Period from Shear-Wave Velocity Profile. Bulletin of the Seismological Society of America,Vol. 108, No. 6, pp. 3431-3445. doi: $10.1785 / 0120180103$.

Zhao J X (1996). Estimating modal parameters for a simple soft-soil site having a linear distribution of shear wave velocity with depth. Earthq. Eng. Struct. Dynam. 25, 163-178. doi: 10.1002/(SICI)10969845(199602) 25:2<163::AID-EQE544>3.0.CO;2-8.

Zhao J X (1997). Modal analysis of soft-soil sites including radiation damping. Earthq. Eng. Struct. Dynam. 26, 93-113. doi: 10.1002/(SICI)10969845(199701)26:1<93::AID-EQE625>3.0.CO;2-A

Zhao J X, Zhang J, Asano A, Ohno Y, Oouchi T, Takahashi T, Ogawa H, Irikura K, Thio H K \& Somerville P G (2006). Attenuation relations of strong ground motion in Japan using site classification based on predominant period. Bull. Seismol. Soc. Am. 96,898913, doi: 10.1785/0120050122.

Zhao J X \& Xu H (2013). A comparison of VS30 and site period as site effect parameters in response spectral ground-motion prediction equations, Bull. Seismol. Soc. Am. 103, 1-18, doi: 10.1785/0120110251.

Zhao J X, Hu J S, Jiang F, Zhou J, Zhang Y B, An X M, Lu M \& Rhoades D A (2015). Nonlinear site models derived from 1D analyses for ground-motion prediction equations using site class as the site parameter. Bull. Seismol. Soc. Am. 105, 2010-2022, doi: 10.1785/0120150019. 